\title{
Basic Income: is it Applicable to Modern States?
}

\section{Temel Gelir: Modern Devletlerde Uygulanabilir Mi?}

\author{
Candoğan Orlu' ${ }^{1}$ (D)
}

\begin{abstract}
Basic income is a concept of a universal and unconditional cash benefit provided to all individuals, without any means test or work-related requirement. The struggles of modern states in sustaining the current social welfare models has resulted in the search for long term alternatives, which hassled to the popularity of basic income in recent decades.

Due to its equal and comprehensive nature, many have championed the basic income idea to promote fairness in income distribution and total coverage. On the other hand, there are strong criticisms against a basic income both on ethical and financial levels. The everlasting conflict of providing an income to every individual even if they are not willing to contribute to society, versus the right to a basic living standard and freedom to work has been discussed. The criticisms and ethical justifications of the system are provided for review. Notwithstanding, financial criticisms, funding problems and adequacy of a basic income scheme is also discussed along with the counter arguments and possible solutions. International applications and experiments in basic income are also briefly presented and their results are commented on.

In conclusion, some variations of basic income are suggested as suitable to solve today's social security struggles. First, it is deduced that basic income could be a supplemental benefit and not a replacement to modern social security schemes due to distribution and funding issues. Secondly, a partial basic income is possible to implement in state owned natural and national resources. And finally, basic income is suggested as an efficient tool to tackle unemployment caused by disappearing professions as a result of technological advancements.
\end{abstract}

\section{Keywords}

Basic income $\bullet$ Citizens' income $\bullet$ UBI $\bullet$ Social welfare $\bullet$ Social security $\bullet$ National subsidies $\bullet$ Social assistance

Jel Codes: I30, H53, H55

1 Corresponding author: Candogan Orlu (PhD Candidate), Marmara University, Institute of Banking and Insurance, Risk Manager, Istanbul, Turkey. Email: candoganorlu@gmail.com ORCID: 0000-0002-4287-4596

To cite this article: Orlu, C. (2019). Basic income: Is it applicable to modern states? Sosyal Siyeset Konferansları Dergisi, 76, 213-237. https://doi.org/10.26650/jspc.2019.76.0007

(C)The Authors. Published by the İstanbul University under the terms of the Creative Commons Attribution License https://creativecommons.org/licenses/by$\mathrm{nc} / 4.0 /$, which permits unrestricted use, provided the original author and source are credited. 


\section{Öz}

Temel gelir, evrensel ve koşulsuz olarak tüm bireylere sağlanan nakit geliri kavramıdır. Modern devletlerin sosyal refah düzenlerinde yaşadıkları zorluklar, devletleri çözüm arayışına itmiştir. Alternatif olarak değerlendirilen temel gelir kavramının da popülerliği son yıllarda bu sebeple artmış.

Temel gelir fikrinin eşitlikçi ve kapsayıcı özelliklerinden ötürü oldukça destek görmektedir. Toplumda tam kapsam sağlamak ve gelir dağılımında adalet sağlamak gibi öne çıkan özellikleri dikkat çekmektedir. Diğer yandan etik ve finansal açılardan güçlü eleştiriler de yapılmaktadır. Her bireye, topluma bir katkı sağlama iradesi olmasa dahi gelir sunmak fikri, temel yaşam ihtiyaçlarını karşılayabilme hakkı ile sonu olmayan bir çatışmaya girmiştir. Çalışmama hakkı ve topluma fayda sağlama yükümlülüğü etrafinda şiddetli tartışmalar yapılmıştr. Eleştiriler ve karşı etik gerekçeleri bu çalışmada değerlendirilmeye sunulmuştur. Finansal eleştirileri göz ardı etmeyerek finansman problemleri ve temel gelir programlarını yeterliliği masaya yatırılmış, karşı görüşler ile birlikte olası çözümler de sunulmuştur. Uluslararası temel gelir uygulamaları ve deneyleri kısaca sunulmuş ve sonuçları yorumlanmıştir.

Sonuç olarak bazı temel gelir uygulama çeşitleri, günümüzdeki sosyal güvenlik sıkıntılarını gidermekte uygulanabilir olarak önerilmiştir. Öncelikle temel gelirin modern sosyal güvenlik sistemlerine, dağıtım ve finansman sorunlarından dolayı, ikame değil de tamamlayıcı bir fayda aracı olarak uygulanabileceği sonucuna varılmıştır. i̇kinci olarak kısmı temel gelirin, kamuya ait doğal ve milli kaynakların olduğu ülkelerde mümkün olabileceği sonucu çıkartılmıştır. Son olarak da temel gelirin, teknolojik gelişmeler sonucunda kaybolacak mesleklerden doğacak işsizlikle mücadele konusunda etkili bir araç olarak kullanılması önerilmiştir.

\section{Anahtar Kelimeler}

Temel gelir • Vatandaşlık geliri $\bullet$ UBI $\bullet$ Sosyal refah $\bullet$ Sosyal güvenlik $\bullet$ Milli sübvansiyonlar $\bullet$ Sosyal yardım • Devlet yardımları

Jel Kodları: I30, H53, H55 


\section{Introduction}

This study takes aim at the applicability of basic income as a potential solution to the struggles of the modern welfare states in general. The widely accepted definition of basic income is provided. In order to understand the concept better, the roots of the basic income idea are taken into consideration in addition to the historical evolutions and transformations which unfold the most recent silhouette observed today. The ethical and economic arguments -from both supportive and critical sides- are presented and evaluated after comparing the inconclusive results derived from the recent basic income implementations and trials in the world. The findings of the study point out that the empirical results are quite limited to offer a decisive answer, yet somewhat promising. Basic income is suggested to be able to solve some of the problems in modern welfare states as an alternative tool, in certain circumstances. However, it would fail if applied as a whole system replacement -mainly due to funding insufficiencies.

There has been a various discussion going on with the basic income concept and the applicability of that concept to the social welfare systems of today. The voices coming from both sides of the argument, for and against, are raised quite strong and loud. However, is the voice of one side actually stronger and louder? This article intends to hear both sides of the debate in order to deduct a productive conclusion, and perhaps raise a couple new questions worth taking into consideration for future developments of the social welfare systems. In order to achieve these goals, the concept of basic income needs to be understood first.

Basic income, is interchangeably used with the terms universal basic income, citizen's income, unconditional basic income (Martinelli, 2017, 4). The widely accepted and used definition of basic income is that; a basic income is an income unconditionally paid to all on an individual basis, without means test or work requirement. It differs from other forms of minimum income guarantees in European Countries by the virtue of the fact that it is paid; to individuals rather than households, irrespective of any other sources of income, without requiring any present or past work performance/willingness (Van Parijs, 1992, 3). Therefore; 
- Every member of a society receives the same amount of cash, regularly and regardless of the individual income/wealth.

- There is absolutely no labour market condition attached to the basic income, such as to be looking for work or to be willing to work.

- There is no reference to prior work history, contributions to the social security system.

- There is no means testing of any sort to qualify an individual for basic income.

\section{Literature Review}

Even though there is a widely accepted and agreed on definition of basic income, there is no consensus on the scope of it. Van Parijs pointed out that basic income does not have to be linked with basic needs. On the other hand there are ideas promoting that basic income, by definition, needs to provide basic security as in obtaining enough food, a place to live, and an opportunity to access medical care. The latter of the ideas of basic income points at the Universal Declaration of Human Rights in 1948 which states in Article 25 that "Everyone has a right to a standard of living adequate for health and wellbeing of himself and his family."

Taking a look at the roots of basic income, one needs to have keen eyes as the origin of the concept goes far back to $18^{\text {th }}$ Century. In 1796, Thomas Paine proposed, in a pamphlet (Agrarian Justice) something radically differentiating from social insurance and public assistance. His proposal, in short words, was to create a national fund to provide a lump sum payment to every citizen reaching 21 years of age, and an annual payment to every citizen who is 50 years old or older. The proposal was basically offering a start-up capital to young people (i.e. enough to buy a cow and cultivate a few acres of land); and an unconditional basic income to the people aged 50 years or more (Foner, 1961, 605-623). It took less than two years for this idea of Thomas Paine to be progressed further by Thomas Spence, in 1797, into a universal basic income. Thomas Spence, in a pamphlet titled The Rights of Infants, defended that all the lands and houses of each municipality should be entrusted to a committee of women, which gives the lands to the uses of the people via auctions. The income generated via these auctions were to be used to cover the public 
expenditures such as government tax, constructions, buildings, repairs etc. And, of course, the surplus to be distributed to all of the individuals in the community equally and fairly (Cunliffe \& Erreygers, 2004, 81-91). Paine and Spence, both agree on the idea of land being the property of the state and any improvement/production coming from the usage of that land to be distributed amongst the people of that state. This idea of the land being owned by the state and the income generated to be distributed to the individuals is the very root of basic income concept. However, this idea and both proposals were lost into oblivion in 1820s after some discussions (Van Parijs ve Vanderborght, 2017, 70-73).

Until the second half of the $20^{\text {th }}$ century, the idea of basic income resurrected by the echoes of egalitarian reformists and thinkers, in the pursuit of a more just social security applications. Prior World War I, the basis of the basic income argument was based on the Catholic belief and the notion of justice. It is observed that many of the supporters of basic income concept(s) leaned their backs to the Bible; deducting that the Earth was created for all the human beings and individual ownership of land is what prevents the deserved justice to be served. Ergo, the land shall not be owned by individuals but by the state, and whatever income generated through the land shall be given to the people living on it. Some of the ideas had been heard and discussed, even gave birth to variations of basic income such as negative income tax; which is a conditional and supplemental version of basic income in a nutshell. However, all the significant ideas brought by basic income supporters including Joseph Charlier, John Stuart Mill, Victor Considerant were dismissed and taken off the table until no earlier than the World War I (Van Parijs and Vanderborght, 2017, 73-78).

The basic income ideas started to be taken seriously after the World Wars with the sprouts of the modern social security systems and welfare states. Although there have been several attempts to implement the basic income in the USA, United Kingdom, and Continental Europe, none of them prevailed for various reasons - mainly due to political concerns having higher priority over the social security issues. In the last couple of decades the debate seems to be fired up as a result of the individual voices for the basic income around the globe uniting under an organization; Basic Income European Network (BIEN). From 1980s to today, the independent national developments and 
attempts gathered an international ground, enabling voices to echo worldwide (Van Parijs and Vanderborght, 2017, 70-98).

In the last decade the support for basic income has grown rapidly, as well as the popularity. The main reason behind this rise is the struggle of the modern welfare state; caused by the aging populations, rising costs of welfare states/ social security, and technological advancements transforming the overall labour market at its very core. There had been a golden era of the Western welfare states, countries with developed economies, after the World War II and up until 1970s; welfare provisions were institutionalized, got increasingly comprehensive and generous (Pierson C., 1998, 12-13). However, this has not been the case since 1980s and welfare state has been reported to be in crisis; becoming the "object of doubts, fundamental critique, and political conflict" (Offe, 1984, 147-148) due to the main reasons given above. In hindsight, this lack of success of the welfare state seems to be inevitable considering the demographic, and socio-economic changes combined with the drastic labour market transformations, which have been observed in the last couple of decades. The consequentially emerging newly salient risks created the potential demand for public expenditure; each becoming a competitor for the scarce resources of the formerly feasible social programs (Pierson P., 2011, 7-18).

The search for solutions and alternatives to the current welfare provisions and social security programs shed light onto new ideas and concepts, including basic income. The public awareness towards basic income raised to a level that is a historical high because of the recent international debates and experiments held by the high income states. Without a doubt, such awareness comes with a never seen before level of support (Martinelli, 2017, 19-34). The 2016 referendum of Switzerland, the universal basic income experiment of Finland, and various studies conducted on international mediums certainly lit some candles in the long darkened part of the room, allowing basic income to meet the eyes of the modern public.

Van Parijs and Vanderborght (2017) define the basic income, provide the roots and the history of the concept. Before explaining the development of the basic income concept until today, it is compared with public assistance and social insurance to point our both the similarities and the differences. The moral case against basic income is discussed and an anti-thesis is proposed. 
After providing ethical justifications, possible funding solutions, political aspects are brought on the table, pointing out that public support is required. For political reasons, the writers guess that a partial basic income with some sort of conditionality is more likely to be accepted and to find wider support. In conclusion, basic income is accepted as a utopia, for the time being. It is pointed out that utopic ideas may be accepted in the long term, if small steps towards the utopia are taken one by one. Therefore, the discussion and development on basic income needs to continue and grow, so that it can be actualized into a solution for the social welfare struggles of today.

Martinelli (2017), summarizes the concept of universal basic income (UBI) and points out the recent developments in the UBI debate, and questions if UBI can be applied in the UK and if so, how. The financing problem of the UBI is tackled and the discussion is elaborated; an affordable UBI would provide inadequate social protections, and an adequate social protection via UBI would be unaffordable. Therefore alternative functions are inquired and the impact of UBI on poverty, labour market and employments are analyzed. The political feasibility of a UBI implementation is also discussed. Martinelli concludes that further research and experiments are needed, however, if UBI to be implemented in the UK, it needs to be partial and conditional scheme rather than a universal and an unconditional payment.

Ebbinghaus and Naumann (2018) take a close look at the welfare reforms in the UK and Germany. Their ultimate goal is to find out the real effect of public opinion and organized interest on the reforms took place in those two countries. Then, the conclusion is widened on a European level. The distinctive aspect of this work, separating this book from all other welfare reform studies, is claimed to be the focal point; the political pressure and the necessity forcing the welfare reforms -rather than the conventional focus on simple politics. The verdict, states that regardless of the common perception of welfare reforms being pushed from above, the success of the pushed-from-abovelegislations highly depend on the public opinion and individual interests. And the opinions and interests can be changed or shifted by organizations, by organized interests. It is pointed out that there still needs more exploration of further factors affecting how the preferences are formed in order deductions to be more concrete, and some methodologies are suggested to do the required further research. 
Jackson (2017) points out the UBI concept gaining popularity, lists some of the criticisms towards it; funding issues and potentially negative labour market impacts. He draws focus on how to tackle labour market/employment and poverty issues while transforming into UBI and how to implement the UBI principals in order to constrain the misusage risks given.

Lacey (2017) provides some thesis and anti-thesis remarks from both sides of the UBI debate, providing some experimental results from Finland and Namibia, and ongoing application examples from Iran and Alaska. It is emphasized that UBI is gathering some significant support and the UBI supporters are gathering empirical evidence to support their side, showing UBI as a legitimate tool to tackle gender-based and/or race-based issues in addition to wealth distribution.

Gliszczynski (2017) states that the discussions on social protection and UBI studies coincided in the last decade, providing a better medium for UBI. As a result of the UBI pilot projects and experiments, the UBI debate evolved into a real debate from being a merely hypothetical one. The current applications of social cash transfers (SCT) are compared to UBI, and SCT have clear advantages in terms of available data, better implementation guidelines, and working examples. He draws the inference that UBI is still unclear in terms of a form, and it lacks the consensus on how a UBI scheme would look like. Consequently, more evidence and work is needed to form a policy model that is agreed on for a UBI scheme.

Townsend (2009) takes a look at the social security in Europe, focusing on the development processes, current obstacles, and lessons learned. The right to social security is compared between the high and low income countries. He concludes that economic and social developments are effective to reduce poverty. $30 \mathrm{OECD}$ countries are put under a microscope to examine the social security-poverty relationship and draws attention to the rise in the social spending on a global scale. The focus also is given to the social security's role in economic and social development in states.

Browne and Immervoll (2017) simulate some UBI scenarios for four particular states. The financing, population coverage, universality and adequacy are compared to the current systems in the chosen countries; Finland, France, Italy, and UK. They infer that everything staying the same, 
converting the ongoing system into UBI would not be adequate nor effective to reduce poverty level in those four countries.

\section{Ethical Debates}

Since the emergence of the idea of basic income, it has faced strong criticisms against it. It is quite common to see harsh criticisms both from ethical and financial perspectives.

Considering the basic income from an ethical point of view; one realizes that the idea itself has been based on ethics. Basic income is a universal and unconditional cash benefit provided to every individual -which promotes equality. The current SCT schemes involuntarily leave out some part of the population which is in need of the support. The reason behind this is hidden behind the conditionality aspect of the current social security systems. Once conditions are introduced to either receive a social support or to be included in a membership of a social security scheme, by definition, some boundaries are drawn. Since it is practically impossible to think of every individual scenario and set peculiarly specific conditions to satisfy every possible individuals' needs, establishing a perfectly just SCT scheme seems improbable. The social security, among other aspects of modern civilization, is constantly evolving according to the different needs - and those needs change almost on a daily basis. For that, conditionality comes with its own flaws; some conditions will apply or not apply to certain individuals or groups in ways those will be deemed unjust -but still lawful. Therefore, it is consequentially inevitable to leave some individuals out, quite unfairly.

On the other hand when the conditionality is ruled out of social security, it solves the inevitable problem introduced above, by bringing in new ethical concerns; the free ride! If an individual is given the opportunity to receive an unconditional income, would he/she work at all? What happens if a vast number of individuals stop contributing to the society, to production, to income generation? These questions raise the alarm of fairness in the heads of the UBI critics, such as Babeuf or Bellamy, and they have a solid point. It would cause a discomfort, if not something severely more catastrophic, some lazy individuals to get a free ride on the backs of hard working others (Van Parijs and Vanderborght, 2017, 101). 
Bertrand Russell emphasizes an asymmetric perception when it comes to work and leisure. According to Russell, rich have been always shocked by the idea of poor having leisure -as leisure has been associated with richness in their minds (Russell, 1976, 11-25). The egalitarian argument kicks in at this point stating that every individual should have a right of leisure, simply as a human right. Supporting this idea, the current socioeconomic conditions could be pulled into the spotlight by arguing that the poor needing to work much more and harder in order to make a living. In this reality we live in, leisure is a luxury and only for the ones who can afford it. So the wealthier an individual gets, more that individual is entitled for leisure; that is simply the rule of the current world. It is utterly impossible to undo this, at least with the current social security tools we have.

Winding back to the argument of nature and creation, nature provided resources highly enough for every individual. However, in order to balance the scales, nature also required some work to gather or make use of those resources; no pain, no gain. In order to achieve some sort of parallel view to this balancing idea, the element of social inclusion could be considered. Social inclusion is the process of improving the terms of participation in society for people who are disadvantaged on the basis of age, sex, disability, race, ethnicity, origin, religion, or economic or other status, through enhanced opportunities, access to resources, voice and respect for rights (UN, 2016, 20). Social inclusion term is highlighted when the importance of engagement and participation in society is being emphasized as a means of improving quality of life and reducing social isolation (Cordier, 2017, 2). Low income and poverty are major hindrance to social inclusion. Poverty and unemployment keep individuals from participating in social life. Civic and cultural activities are a major part of social life and considered to be crucial for social inclusion. Individuals having low income or living in poverty commonly lack the social networks which constitute the main source of support, power and agency to tackle social exclusion issues (UN, 2016, 2-6). Therefore it is in order to reach a conclusion that low income overlaps with social exclusion and lowers an individual's (or household's) capacity to participate in society (Sen, 2000, 44-45).

In the case of an UBI scheme providing an income for the most basic needs of individuals, the right of not to work is given to everyone; compared to -so called- becoming a voluntary slave. However, one certainly needs to bear in 
mind that in the modern civilizations, social acceptance is a huge part of life. And employment is the very element which confers social identity, as well as the intermediary of social acceptance in an individual's life (UN, 2016, 42). One needs to work, achieve and/or earn some achievement in order to scale up and be included in the society at various levels. Some commodities are deemed as necessities, not because they are actually necessary to live, but because they are necessary to engage in public life without shame and disgrace (Smith, 2007, 676). So there certainly is a motivation to work, in order to move to a living standard higher than 'just enough to live' and reach a life style beyond the basic needs -if not for simply being accepted in social life.

Hayek, defines freedom or liberty as the reduction of coercion of individuals by others (Miller, 2010, 39). Therefore, people would have a true freedom in terms of not being coerced to a life-work balance by others, and they would have the liberty to make life/work choices according to the social status they would like to achieve. In support of this argument, one should note that in the modern socioeconomic life, there is a huge amount of essential work performed which is going either unpaid or vastly underpaid; especially at home. Besides, if an individual is content with just basic needs to be covered and not willing to work for more, that should be fine. That is the life choice of that individual and those individuals would not constitute a threatening population as the majority will be motivated with the desire for more according to UBI supporters. Yet, that might also cause a devastating shortage on the supply of the low-end jobs. One optimistic answer to that would be; due to the decreases in the supply of such low-end jobs and the still remaining demand for them, such jobs would no longer be low-paid and the market would balance itself. If that would be the case, even the level of the product or service might rise in quality. Simply because the workers of such jobs would have the means and the motivation to better themselves in the profession.

\section{Economic Debates}

Leaving the ethical debates as they are, inconclusive and somewhat still hypothetical, the financial criticisms are very real when it comes to providing unconditional universal income for all. Let's consider switching to UBI from the current social insurance or social protection schemes from the state point of view. Assuming the same amount of tax is collected, budget transfers are 
made the same, and the total amount of available cash is the same on the receiving end. However, on the giving end, the number of individuals getting the benefit will increase drastically. Current SCTs in many states are directed to the specific people on conditional basis. Disabled people, unemployed people (who are willing to work and actively trying to find a job), people who have been paying social security premiums/taxes are a few examples. Simply, the same amount of cash (or benefits worth of cash) will be distributed equally but to a lot more individuals. Which would, of course, cause a severe reduction in per capita benefit -or in this case, basic income. Considering even the high income states have been looking for social security reforms due to the forecasts and calculations showing that the current social security systems are not sustainable in the long run, it can easily be concluded that a UBI would fall quite short of adequate in providing an income to cover the very basic needs.

Although the argument presented above is deemed to be too simplistic, it is painfully true for the UBI supporters. The main way to financially support UBI would be through taxes, a torturing amount of rise in the taxation would be necessary for a perfectly adequate basic income; which is nothing but unfavorable -in the kindest of words. The taxation could be targeted towards the high income individuals, establishing a form of cash transfer from the rich to the poor. Two possible applications comes to mind; first is via income tax regulations, but that brings new opposition and even more problems to the table, ergo it is not feasible. The only viable taxation option might be in the form of consumption tax, like VAT. However, a conventional consumption tax would considered to be a band-aid-solution; a very short term illusion (Van Parijs and Vanderborght, 2017, 157). The reasoning behind Van Parijs' deduction is that the consumption tax would boost the prices up, increasing the costs of individuals, and in result, undoing the very effect that is the reason of its creation; improving the quality of life. A contribution to this idea would be applying a consumption tax to the luxury goods, specifically to fund basic income. This would face less resistance as the luxury consumption, ergo basic income tax, can be considered as voluntary spending. One would have the freedom to buy and not to buy a luxury product or service, unlike the basic necessities. Automatically a form of social cash transfer from the high income individuals to low income individuals would have been set, with minimal opposition, considering the case and benefits are marketed right, in the eyes of the society. 
There are also alternative funding methods suggested by many UBI supporters such as carbon/pollution tax from industrial (polluting) corporations, oil tax from energy companies and such, with the reasoning that the nature belongs to everyone, therefore any damage caused to the common commodities needs to be paid in a sort of fine -which could fund the UBI. A similar suggestion also sticks out claiming all the natural resources and land to be rented out, and the fee for the usage of the 'collective asset' to be used to fund UBI. This latter idea shows great similarity for its ancestor in the $18^{\text {th }}$ century, it almost is an echo of the ideas of Paine and Spence. The modern version, in addition, proposes the clean energy production income, generated from the wind, water, and Sun, also to be treated as collective assets.

Considering all of the above, UBI supporters tend to gather around modest versions of basic income rather than fighting for a utopia, a losing battle: the perfect UBI scheme that covers every individual and every basic need. While softening the UBI, categorical, occupational, and partial models are sticking out. Categorical basic income ideas are quite parallel to current social insurance schemes around the world, such as universal child benefits and elderly care benefits and/or pensions. Another idea is an occupational basic income which targets specific jobs, sectors of labour market those are deemed in need for such a cash support. In both cases some group(s) of people are entitled to receive a basic income; snapping off a fundamental attribute of UBI and leaving merely an illusion of universalism. Therefore each idea introduces a sort of conditionality, which automatically brings inevitable unjust selection issues. One might claim this constitutes a huge irony; the suggestion softening UBI to make it feasible, conflicts with the core idea causing the emergence of UBI in the first place.

A partial UBI is also suggested as a feasible option; UBI does not necessarily need to cover the basic needs entirely, but provide monetary support as much as it feasible can. Therefore UBI would be a supportive tool in social security systems rather than a replacement of the entire system. This idea is quite moderate and feels injectable in the modern societies, although, it is quite unclear if it would be beneficial at all considering the funding efforts and the benefits it is intended to replace. 


\section{UBI Experiments, Trials, and Implementations}

There have been some effort to seek answers to various inquiries regarding the effects of a possible UBI, in effort to battle against poverty and labour market efficiency struggles, of course alongside unemployment.

KELA of Finland conducted an UBI experiment for 2 years, recently had concluded in December, 2018. Randomly selected 2,000 participants from the unemployed applicants were paid $€ 560$ per month. The initial findings were published, indicating the UBI reduced the stress level of participants and they were happier compared to the control group. However, the experiment seems to fall short considering its main motivation; the effect on labour market participation was not changed-for better or for worse- by the income injection. The expectation was the participants to be able to spend more time looking for jobs and investing in themselves, allowing them to actively participate in the labour market as a result. Findings indicate that some short term and part time jobs were taken by the participants, however the changes were statistically insignificant.

In 2011, UNICEF funded a UBI experiment with the coordination of Self Employed Women Association (SEWA) of India, in 8 villages in rural India. Every adult was paid 300 Rupees, and every child 150 (the payments initially were 200 to 100 respectively but were increased). The initial results of the 18 month long pilot project were presented in a conference in Delhi, on March 30-31, 2013. The preference of support by the participants to the pilot project were cash, opposed to subsidies. The results point out that the living conditions, health, nutrition improved first. The children attended school in larger numbers as an outcome. The children, women and the disabled were also observed to be empowered with the individual income they received; the disadvantageous groups experienced a more positive effect in terms of bargaining power in the household. On the contrary to the critics of UBI and the pilot project, the extra cash income did not result a worsening situation in the labour market; individuals made small-scale investments to grow crops, buy sewing machines, establish little shops. Therefore there was a positive effect on the production and labour market in the small society. Labour force production, equality, economic growth seemed to be changed in the positive direction. In India, it is claimed that universal schemes would be less costly as the current targeted methods have high exclusion conditions, ergo high inspection costs (Standing, 2013). 
There have been several other pilot programs and experiments in the low income countries such as Namibia but none of which seems to provide conclusive and significant results due to the lack of data and low number of participants, in addition to lack of diversity in the trials.

There had been some implementations of UBI which were short lived. In Iran, the oil price was increased to the international level, and the surplus income was given back to the Iranian people as a cash benefit. This move targeted to motivate people use less fuel oil, decrease natural consumption and provide more benefit to the state and to the people through the increase in oil exports. Quarter of the revenues were used to subsidize the companies who took a direct hit from the policy, the rest was distributed to 7 million Iranians. The income started as $\$ 20$ per month and rose to $\$ 60$, which was roughly $13 \%$ of GDP per capita. However, trade sanctions and global politics held Iran back from continuing this policy of 2010. In 2006, Alberta Government in Canada gave a one shot, tax free "prosperity bonus" to the 3.3 million residents from the oil revenues of the state. The scheme paid $\mathrm{C} \$ 400$ and was said to continue but it never did. Many others also failed to establish a sustainable basic income (Perijs \& Vanderborght, 2017, 149-152).

Alaska Government on the other hand had a unique achievement. In 1970s the Prudhoe Bay oil field was secured for the citizens of Alaska. Term Governor Jay Hammond, was concerned that the reserve would only benefit the current generation and therefore he set up a fund to be invested by the oil revenues, so the wealth would be preserved for the future generations. The fund has been paying dividends to Alaska residents in the level of 3\% of GDP per capita, which equals \$2,072 per annum in 2015 (Perijs \& Vanderborght, 2017, 93-952).

Similar and relatively localized UBI efforts are seen in North Carolina and Macau. The Eastern Band of Cherokee, decided to distribute the casino revenues in their own small community and since 1996, each member of the tribe has been receiving a cash benefit worth $25 \%$ of the North Carolina's GDP per capita. The small island of Macau's policy is very similar; it pays to its habitants an amount that is $1 \%$ of the -relatively very high- GDP per capita of the island (Perijs \& Vanderborght, 2017, 152).

OECD raised a question; what would happen if UBI is implemented in a modern welfare state? In pursuit of an answer, Browne and Immervoll 
calculated what the overall picture would be if the current schemes were transformed into UBI in Finland, France, Italy, and the UK. The four European states were chosen as they are somewhat comparable in terms of their economies, and they all differ in their existing social security schemes. Hence, the deductions would be more objective.

Table 1

The change in poverty risks by comprehensive basic income

\begin{tabular}{|c|c|c|c|c|c|}
\hline & & \multicolumn{4}{|c|}{ In poverty under basic income? } \\
\hline & & \multicolumn{2}{|c|}{ No } & \multicolumn{2}{|c|}{ Yes } \\
\hline \multirow{4}{*}{$\begin{array}{l}\text { In poverty under } \\
\text { existing system? }\end{array}$} & \multirow{2}{*}{ No } & UK: $83 \%$ & Finland: $90 \%$ & UK: $7 \%$ & Finland: $3 \%$ \\
\hline & & France: $89 \%$ & Italy: $83 \%$ & France: $5 \%$ & Italy: $4 \%$ \\
\hline & \multirow{2}{*}{ Yes } & UK: $2 \%$ & Finland: $2 \%$ & UK: $8 \%$ & Finland: $5 \%$ \\
\hline & & France: $2 \%$ & Italy: $4 \%$ & France: $4 \%$ & Italy: $9 \%$ \\
\hline
\end{tabular}

Source: BROWNE, James \& Herwig IMMERVOLL. Basic Income as a Policy Option: Technical Background Note Illustrating Costs and Distributional Implications for Selected Countries, OECD Directorate for Employment Labour and Social Affairs, 2017.

Table 1 clearly shows that the number of people in poverty would significantly increase in UK, Finland and France, should the system be transformed into basic income. The negative effects seems to be less significant in Italy, however, one must consider the higher poverty rate which partially points to a larger income gap.

Basic income surely fixes the benefit gaps in social security schemes. Once basic income is replaced with everything staying the same, in the selected four countries the costs and distributional implications seem to be anything but cost-effective in the pursuit of tackling poverty. Taken a careful look at the four selected countries, the outcomes are even negative in terms of poverty. Basic income, replacing the current social support tools causes poverty rate to increase in Finland, France, and Italy. In the UK, the gap between the poverty line and the income of people in poverty closes a bit, however, the number of people living in poverty stays the same. When it comes to targeting of social supports, in Finland and France, the social supports become much less well targeted. In Italy though, the targeting of social support does not change much as the current system of social support is not considered to be well targeted either. It is also evaluated that even if the taxes are increased significantly, BI does not reduce poverty in a significant manner (Browne and Immervoll, 2017). 
Chart 1. The change in poverty risks by comprehensive basic income

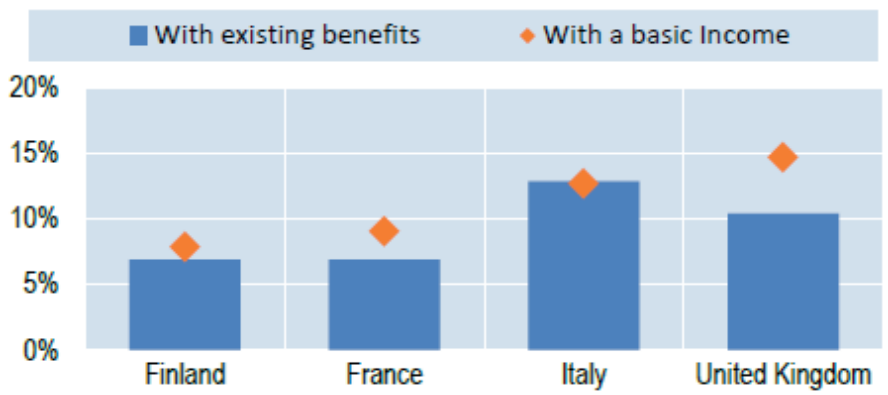

Source: BROWNE, James \& Herwig IMMERVOLL. Basic Income as a Policy Option: Technical Background Note Illustrating Costs and Distributional Implications for Selected Countries, OECD Directorate for Employment Labour and Social Affairs, 2017.

Chart 1 provides the hypothetical results of a comprehensive basic income scheme in the four selected states. In such a case, poverty risks are seemed to rise. It is clear that the UK, France, Finland and Italy would not benefit from a basic income scheme with the current tax schemes.

In order to have a better understanding of the required tax increase for a perfect universal basic income scheme, the monthly basic income amounts are given below for the chosen four countries, right next to the health expenditure per capita of corresponding countries:

Table 2

Basic income vs. health expend. per capita vs. poverty line for Finland, France, Italy, and UK

\begin{tabular}{|l|r|r|r|}
\hline Country & $\begin{array}{c}\text { Basic Income (Adult) } \\
\text { Monthly }\end{array}$ & $\begin{array}{l}\text { Monthly Health } \\
\text { Expenditure per } \\
\text { Capita }\end{array}$ & $\begin{array}{c}\text { Poverty Line for } \\
\text { Single Person }\end{array}$ \\
\hline Finland & $€ 527$ & $€ 310$ & $€ 909$ \\
\hline France & $€ 456$ & $€ 364$ & $€ 1,074$ \\
\hline Italy & $€ 158$ & $€ 263$ & $€ 737$ \\
\hline UK & $£ 230$ & $£ 273$ & $£ 702$ \\
\hline
\end{tabular}

Source: OECD. Health Expenditure and Spending, Capita current prices https://stats.oecd.org/index.aspx? DataSetCode=HEALTH_STAT\# (10/05/2019). \& Basic Income as a Policy Option: Technical Background Note Illustrating Costs and Distributional Implications for Selected Countries, OECD Directorate for Employment Labour and Social Affairs, 2017.

According to the numbers given in Table 2, it is quite obvious that the basic income levels of the four countries fall well below the poverty lines. However, the more striking revelation is that in the case of UBI replacing the current social support schemes, the individuals relying on their basic income 
would not even be able to cover their medical expenses. Therefore it is safe to state that basic income cannot possibly be used to replace the current social security systems in order to tackle poverty.

\section{Conclusion and Discussion}

The concept of UBI is quite just and provides equality. The notions themselves are basically music to ears of the most. But, were it so easy? There are some ethical and financial concerns those need to be addressed and satisfied in order to take further steps, for sure.

The ethical criticisms focus on the risk that once individuals get a right to an income, they may not work at all and that would cripple the entire production, labour market; in a nutshell, crack the entire system. The fear is that, UBI would cause a shortage in the low-paid jobs as people working in those jobs rather not work at all. This fear is deemed pointless by the UBI supporters; because individuals would still have the necessity to be socially included and respected. And those cannot happen if an individual does not work in today's society. In addition, UBI ideally covers the very basic needs of an individual. In order to have a better quality of life, maintain a higher level in the society, people would still have quite a motivation to work. This very approach is backed up by the UBI experiments conducted in India. Unconditional cash benefits were given to low or no income individuals. The very first actions they took were to better their life conditions, and try to increase their level of income by micro-investments and entrepreneurial efforts. In addition, egalitarians think individuals could have the freedom not to work if they are content with the barely-enough-to-live life quality.

A close cousin of the debate given above regarding the potential effects of UBI on the labour market is; whether UBI would cripple or enlarge the labour market? Being a rather hypothetical debate, both sides have firm statements. Assuming a UBI scheme to provide a basic income around the minimum wage level in modern societies, the labour market would suffer due to the low-wage jobs will not be preferred anymore -suggests the UBI critics, similarly. However, the antithesis confirms the reasoning but suggests the exact opposite as an outcome. Since there will be a basic income enough to cover the basic needs, some people working multiple jobs or working and taking care of children/elderly at the same time, would be more comfortable 
in choosing low income jobs, part time jobs or one job at a time -in order to create more time to take care of the loved ones in need. As a result, the labour gap created by the ones fall out, as suggested by the critics, would be filled by the basic income receivers. In the end, it is claimed that the labour force would flourish, not dry out. UBI at such a level would only cause a shift in the labour market, opening up for more job opportunities and more participation. This defense is only slightly backed up by some individual examples in the Finnish UBI experiment.

Ethical criticisms and justifications all have some solid grounds. The studies and experiments do tilt the balance in favor of UBI for a tiny bit, however, still lacking the adequate weight to be conclusive. All the conducted experiments consist of very small pilot groups and they lack diversity. Therefore none of the findings are conclusive nor significant enough to lead to a firm conclusion. In order to predict or simulate the human behavior in the case of receiving an unconditional basic income, much more research and larger scale experiments need to be conducted. The results may, and most likely will, vary according to the sociological, cultural, demographic and economic variables. Therefore, no certain verdict could be reached via the data available at this point, at least on the ethical level of a basic income scheme.

Today, with the data available at hand, the only meaningful debate, therefore, could be the financial one. The main financial criticism of UBI is about the funding. The supporters claim a UBI scheme would boost the GDP of a country so the funding through taxation would be not as drastic due to the increase in the income. However, there is no reliable empirical evidence or study backing up that idea, merely theoretical ones. Since the UBI effect of GDP cannot be simulated in a credible way, but with mere assumptions, the simulations and evaluations require current national incomes and expenditures to be used.

Circling back to the question; is it possible to implement a UBI scheme? According to the calculations and estimated results of Browne and Immervoll, definitely not -at least as a form of replacement for the current social security systems. Should that be the case, the overall poverty and poverty rates increase with a UBI transformation. However, it has been shown by experiments and implementations that the health, happiness and quality of life benefit from cash benefits applied to the people in poverty. UBI might be implemented as 
a supportive tool to replace the cash benefits applied to the certain parts of the society, just like the experiments conducted in India.

In parallel to the conclusion above, the supporters of UBI, such as Van Perijs and Vanderborght, already point out that the perfect UBI is a utopic idea as it is. The only possible way to achieve this utopia would be transforming the states into social states and all the marketization to be nationalized back. If the states own all the lands and natural resources, individual ownership would be ceased. By transferring the individually owned estates to the states to be deemed as common assets, only then there might be enough resources to provide a basic income, which could have a possibility to satisfy the basic needs of the individuals. This scenario is fundamentally going back to the 18th Century idea of Paine and Spence. This option is rationally ruled out as currently there is no sign of a remote possibility for restructuring the entire society nor un-globalizing the entire trade.

To conclude, in the light of the emphasized deductions above, the solely practicable variant of basic income could be of supplemental nature to the current social security schemes. One undisputable finding is that, the healthcare systems cannot be replaced by basic income schemes as the distribution effect of basic income seems to be most unfruitful in this particular area.

In order a basic income scheme to prevail in modern security systems, it seems that the attribute of minimizing bureaucracy and simplistic characteristic should pinpointed. The basic income schemes need to come forward by the ability to cut costs, save time and provide the perception of equality by the society. Therefore the complex and highly conditional social support schemes need to be targeted such as old age pensions, child supports, unemployment and similar social insurance schemes could be gathered under one roof, and paid as a categorical basic income.

Additionally, partial basic income would be most beneficial where the state owns and/or trades the natural resources or national assets. Oil refinery/ production, national lotteries, state owned prison industry, nationally governed tourism schemes, rent/lease of state owned assets and alike income generating national assets are perfect opportunities for partial basic income schemes. The state wide scheme in Alaska based on oil, tribal scheme of Eastern Band of Cherokee, and city scheme of Macau are perfect examples. The nature of the 
income generating national asset will certainly shape the type of distribution regime; whether to directly distribute the revenues or set up a fund to pay dividends highly depend on various elements, therefore case specific models need to be created. It needs to be emphasized that even in the successful application examples of basic income, the cash benefit is not enough to cover basic needs to live. Partial basic income needs to be evaluated and designed to increase the welfare, individual life quality, and individual happiness rather than the utopia of covering for all the basic needs. Howbeit, any attempt to set up a basic income scheme without the natural or national income generating resource, would inevitably bow down to funding mishaps, and result in beyond the pale taxation requirements.

Basic income, as a suggestion, could be a fair and effective way to battle the unemployment of certain jobs those will disappear in the foreseeable future with the developing technology in production and business processes. Such employments gaps and employments shifts had happened before in agricultural and industrial revolutions; some jobs disappeared and new jobs were created -and due to computerization, it will happen again (Frey \& Osborne, 2013, 44-45). This change has been happening and according to OECD 2019 Future of Work Report, employment in manufacturing went down $20 \%$ while in service industry it rose $27 \%$ due to this transformation in employment. The same report estimates $32 \%$ jobs will change significantly and will have different requirements of skill sets, and $14 \%$ jobs will be completely automated. These results point in the same direction of Frey and Osborne's study, differentiating with their estimation of $47 \%$ when it comes to the jobs at risk due to automation and computerization. Frey and Osborne explain the difference by pointing out that the scope and methodology of each study is different, especially in the number of jobs taken into consideration. Regardless of the differences, it is clear that some unemployment is imminent as the newly created jobs will have a totally different skill set than the lost ones. This will result an employment gap for low skilled jobs. In order to tackle this future problem a basic income scheme would be most useful.

A governmental institution could specify the jobs who are lost at the time (or will be lost) due to technological advancements, and list the sectors, industries, jobs which fall into that category. The unemployed who fall into the specified categories will need to acquire a new skill to find job; ergo they 
could be entitled to a basic income for a certain period of time -let's say three years. The basic income could support the unemployed while they work on acquiring new skills, learn new professions and build some experience in the field until they reach a level of expertise where they can fund their own life. The question would come to mind, of course, what if they do not invest in themselves and end up in the same exact situation after the basic income expires -just like it happened in Finnish experiment? Would it be a socially applicable solution to let them be and consider it as a freedom of choice? That is a question highly debatable and also dependable; and should be answered by case specific discussions.

On final note, basic income certainly has attractive aspects and some draw backs. However, the uncertainty of the basic income concept allows a huge flexibility which can be used in the advantage of basic income supporters. Considering the low bureaucracy, fast and easy implementation basic income could be very useful tool to tackle specific social security problems. Even though some alternative schemes of basic income are suggested above, each and every one of them needs to designed to the specific demography, culture, needs, and conditions of the area of implementation. In this case, one size, does not fit all -but could be resized as desired.

It is suggested to conduct basic income experiments to a wider scale and with much more diversity to obtain more conclusive results. For example, employed individuals and individuals living above the poverty line (maybe even the middle class) need to be included in the experiments in order to derive more accurate results to the labour market. The tendency of people to invest in themselves to acquire new skill sets and learn a profession -in the case of permanent unemployment due to the cease of their profession as a result of technological transformation- needs to be researched an evaluated in order to implement the suggested ideas in the conclusion.

Basic income implementations require careful and local considerations regarding the cultural and national backgrounds. It is almost certain that each community would react differently, and formulation needs to be tailor made for the basic income scheme to fit to the each and every particular society.

Grant Support: The author received no financial support for this work. 


\section{References}

Browne, J., \& Immervoll, H. (2017). Basic Income as a Policy Option: Technical Background Note Illustrating Costs and Distributional Implications for Selected Countries, OECD Directorate for Employment Labour and Social Affairs.

Browne, J., \& Immervoll, H. (2004). Mechanics of replacing benefit systems with a basic income. The Journal of Economic Inequality, 15(4), 325-344.

Cunliffe, J., \& Erreygers, G. The Origins of Universal Grants ( $1^{\text {st }}$ Edition), Palgrave Macmillan, Basingstoke.

Ebbinghaus, B., \& Naumann, E. (2018). WELFARE STATE REFORMS SEEN FROM BELOW Comparing Public Attitudes and Organized Interests in Britain and Germany ( $1^{\text {st }}$ Edition), Pelgrave Macmillan, Hampshire UK.

Foner, P. S. (1961). The Life and Major Writings of Thomas Paine ( $1^{\text {st }}$ Edition), The Citadel Press, New York.

Jackson, A. (2017). Basic income: A social democratic perspective. Global Social Policy, 17(1), 101-104.

KELA (2016). Form idea to experiment Report on universal basic income experiment in Finland. Working Papers 106 / 2016, KELA Finland.

Lacey, A. (2017). Universal basic income as development solution? Global Social Policy, $17(1), 93-97$.

Miller, E. F. (2010). Hayek's The Constitution of Liberty, $1^{\text {st }}$ Edition, The Institute of Economic Affairs, London.

Martinelli, L. (2017). Assessing the Case for a Universal Basic Income in the UK. Bath: University of Bath IPR Policy Brief.

Mckay, A. (2005). The Future of Social Secuity Policy Woman, work and a Citizens' Basic Income, $1^{\text {st }}$ Edition, Oxon UK, Routlegde.

Noguera, J. A. (2018). The political debate on basic income and welfare reform in Spain. Social Policy \& Society, 18(2), 1-11.

OECD (2017). Basic Income as a policy option: Can it add up? Policy Brief on The Future of Work, OECD Publishing, Paris.

OFFE, C. (1984). Contradictions of the Welfare State, ( $1^{\text {st }}$ Edition), London, Routledge Library Editions.

Piachaud, D. (2016). Citizen's Income: Rights and Wrongs, CASE/200 Paper, Center for Analysis of Social Exclusion, London School of Economics, London UK.

Pierson, C. (1998). Beyond the Welfare State: The New Political Economy of Welfare, $2^{\text {nd }}$ Edition, Cambridge: Polity Press.

Pierson, P. (2011). The Welfare State Over the Very Long Run, ZeSArbeitspapier (University of Bremen), No: 02.

Russell, B. (1976). In Praise of Idleness and Other Essays, Unwin Paperbacks, London. 
Sen,A. K. (2000). Social exclusion: concept, application, and scrutiny. Social Development Paper No.1 (June), Manila: Office of Environment and Social Development, Asian Development Bank.

Smith, A. (2007). Wealth of Nations, Digital Edition, MetaLibri, Lausanne.

Standing, G. (2017). Basic Income: And How We Can Make It Happen, Kindle Edition, UK, Pelican.

Standing, G. (2013). India's experiment in basic income Grants. Global Dialogue Magazine of the International Sociological Association, 3(5), International Sociological Association.

Townsend, P. (2009). Building Decent Societies, $1^{\text {st }}$ Edition, Hapmshire UK, Palgrave Macmillan.

United Nations (2016). Leaving no one behind: the imperative of inclusive development. Report on the World Social Situation 2016, New York.

Van Parijs, P. (1992). Arguing for Basic Income Ethical Foundations for a Radical Reform, $1^{\text {st }}$ Edition, London: Verso.

Van Parijs, P., \& Vanderborght, Y. (2017). Basic Income: A Radical Proposal for a Free Society and a Sane Economy ( $1^{\text {st }}$ Edition), Cambridge Massachusetts, USA, Harvard University Press.

Von Gliszczynski, M. (2017). Social protection and basic income in global policy. Global Social Policy, 17(1), 98-100.

\section{Internet Resources}

Cordier, R., Ben Milbourn, B., and others (09 June 2017). A systematic review evaluating the psychometric properties of measures of social inclusion, PLoS One, Access Date: 01 June 2019, 12(6): https://doi.org/10.1371/journal.pone.0179109.

Frey, C. B., \& Osborne, M. A. (17 September 2013). The Future of Employment: How Susceptible are Jobs to Computerization?, University of Oxford, Oxford Martin School, Access Date: 20 May 2019, https://www.oxfordmartin.ox.ac.uk/downloads/ academic/The_Future_of_Employment.pdf.

Frey, C. B., \& Osborne, M. A. (13 April 2019). Automation and the future of work understanding the numbers, University of Oxford, Oxford Martin School, Access Date: 20 May 2019, https://www.oxfordmartin.ox.ac.uk/ opinion/view/404.

KELA (2019). Experimental Study on universal basic income, Access Date: 19 May 2019, https://www.kela.fi/web/en/basic-income-experiment.

KELA (08 February 2019). Preliminary results of the basic income experiment: selfperceived wellbeing improved, during the first year no effects on employment, Access Date: 19 May 2019, https://www.kela.fi/web/en/news-archive/-/asset_publisher/ 1N08GY2nIrZo/content/preliminary-results-of-the-basic-income-experiment-selfperceived-wellbeing-improved-during-the-first-year-no-effects-on-employment. 
Lucarellı, S., \& Fumagallı, A. (2008). Basic income and productivity in cognitive capitalism. Review of Social Economy, 66(1). Access Date: 1 June 2019, https://doi. org/10.1080/00346760802063000.

OECD (2019). Future of Work, OECD Employment Outlook 2019, Access Date: 21 May 2019, http://www.oecd.org/els/emp/future-of-work/data/.

OECD. Health Expenditure and Spending, Capita current prices, Access Date: 10 May 2019, https://stats.oecd.org/index.aspx? DataSetCode=HEALTH_STAT\#.

OECD (2018). Spending on Health: Latest Trends, 2018, Access Date: 10 May 2019, https://www.oecd.org/health/health-systems/Health-Spending-Latest-Trends-Brief.pdf. 
